Orissa Journal of Commerce

Vol. 42, Issue 1, Jan-March 2021

ISSN: 0974-8482

(C) OJC India. All Right Reserved

URL : www.ojcoca.org

DOI: https://doi.org/10.54063/ojc.2021.v42i01.04

\title{
Impact of Investors' Sentiments on Selected Sectoral Indices Return Volatility: Special Reference to NSE
}

\author{
Pooja Chaturvedi Sharma \\ Assistant Professor, Gitarattan International Business School, Rohini, New Delhi.E-mail:poojamitsharmaa@gmail.com
}

\author{
To cite this paper \\ Sharma, P. C. (2021). Impact of \\ Investors' Sentiments on Selected \\ Sectoral Indices Return Volatility: \\ Special Reference to NSE. \\ Orissa Journal of Commerce. 42(1), \\ 44-58.
}

Keywords

NIFTY, Investor sentiment, Stock returns, Sectoral index, Volatility, Asset pricing

JEL Classification G32, G41, G100, G170

\begin{abstract}
The study attempts to assess the influence of investor sentiment on selected sectoral indices returns volatility in the Indian stock market over the period from 2015-2019. GARCH, EGARCH, and Bivariate VAR models were applied for data analysis after checking unit root issue of the data. Nine Sectoral indices namely NIFTY Oil and Gases, NIFTY Metal, NIFTY Media, NIFTY FMCG, NIFTY Financial Service, NIFTY Consumer Durables, NIFTY Auto, NIFTY Bank, and NIFTY IT are considered. A significant influence of investor sentiment on sectoral indices return volatility is traced. The stronger the influence of investor sentiment and higher will be the current market volatility. The results of this study may assist individuals, institutional investors, and the government for an improved understanding of the Indian stock market and to upsurge their returns by integrating investor sentiment into their decisionmaking.
\end{abstract}

\section{Introduction}

Investor sentiment is the general outlook of investors regarding financial markets. This outlook does not depend on the stream of elementary information. When the market gives opposite returns as expected by investors, massive volatility in stock prices can be observed due to major portfolio liquidation as a result of investor sentiment. This results to a lot of market volatility. Investor's sentiments play a crucial role in investment decisions regarding the purchase of stocks. Volatility plays a crucial role in asset pricing as it leads to alterations in the financial assets risk. Wants, cognitive errors, and emotions of investors greatly influence their choices regarding specific stocks. These are generally the traders who do not study the growth prospectus but only look forward to the risk associated with the stocks. These investors even at times create chaos in the market by their understanding as they do not have sufficient knowledge about the stocks.

In financial markets, volatility prediction is imperative for evaluating investment risk. Volatility is the extent to which stock values variate in the stock market. The majority of market options for pricing depend on a volatility parameter. Stock return volatility has majorly been worked regarding trading volumes, level of risks, and other quantitative variables; but a very small portion of available 
literature associates this with investor psychology, emotions, or sentiments. Investor sentiment has a pivotal influence in affecting the volatility of stock returns and needs continuous assessment to keep a tab on changing investor sentiment towards stock return, so a study with the latest investor sentiment is the need of the hour. Another research gap was identified by Kim and Nofsinger (2008) and Chen, Chen, and Lee (2013) in their studies and guided the researcher to conduct this study in India. Kim and Nofsinger (2008) mentioned in their research work that Asians are susceptible to be affected by behavioral biases more comparatively than people of other cultures and therefore, future research should be conducted in these nations. Chen, Chen and Lee (2013) investigated the influence of investor sentiment in Asian markets but specifically mentioned as future scope to conduct a similar study in an emerging market to fulfill the literature gap as most of the investor sentiment studies focussed on mature markets like the USA, Europe, etc. This study also fills the research gap in available literature by linking investor sentiment with the returns of sectoral indices; which is a less explored domain of NSE. To fulfill all the identified gaps, the objectives of this research work are to assess the association and influence of investor sentiment on selected sectoral indices' returns volatility.

Secondary data have been used in the study. To fulfil the research objectives, GARCH and EGARCH, Bivariate VAR model have been applied. Augmented Dickey-Fuller (ADF) test was applied for checking stationarity. Findings of this research work mentioned a significant impact of investor sentiment on selected sectoral indices return volatility. The theoretical implication of this study is that it will develop a literature base of emotional finance and expand the base of behavioural finance. This study will work as a bridge between qualitative and quantitative dimensions of finance and will give readers a new understanding of finance. The results of this study may assist individuals, institutional investors, and the government for an improved understanding of the Indian stock market and to upsurge their returns by integrating investor sentiment into their decision-making. The subsequent segment reviews the available literature on the variables of interest in the study. The next segment briefs about the research methodology followed. The data analysis done to test the hypotheses has been shown in section 4 . The last section concludes the study through findings, discussion, implications, and conclusion.

\section{Review of Literature}

Theoretical support of stock return volatility can be found in the work of the theory of Black (1976). His theory affirms that volatility in stock returns is largely instigated by the leverage effects and it intrinsically escalates the riskiness (Raju and Ghosh, 2004). Lee, Shleifer, and Thaler (1991) mentioned that investor sentiment is a part of investors' anticipations regarding stock returns. Baker and Wurgler (2006) noted that investor sentiment usually indicates investors' tendency to contemplate stocks. Corresponding with this idea, Brown, and Cliff (2004) found a robust association between investor sentiment and stock market returns. Brown and Cliff (2005) found a stronghold of investor sentiment in mispricing the US stock market. Chung, Hung, and Yeh (2012) inspected variations in investor sentiments during various business cycles and found that sentiment reliability is eloquent only during the expansion, whereas during recession period it is not significant. According to Henderson, Jegadeesh, and Weisbach, (2006), investor sentiment has a positive association with government bonds and their market returns. 
Numerous scholars opine that investor sentiment not only elucidates the logic behind other risk factors but it also impacts stock returns and its determining factor for explicating the risk-return relationship (Shefrin, 2015; Uhl, 2014; Zhang, 2008). Ling et al. (2013) and Baker and Wurgler (2007) mentioned the positive linkage between investor sentiment and stock market returns. Dash and Mahakud (2013) and Chung, Heng, and Yeh, (2012) concluded that the influence of investor sentiment on returns is long-lasting on stocks and it's difficult to be spread away by arbitrage. They also mentioned that sentiments have a substantial impact on stock prices particularly in the emerging stock markets. Kling and Gao (2008) found in their research that in China stock returns are not influenced by investor sentiment. Research work of Audrino, Sigrist, and Ballinari (2020) mentions that attention and sentiment affect considerably upgrade volatility predictions, though the extent of upgradations is comparatively small from an economic perspective. Brown and Cliff (2004) and Finter et al. (2010) also found the same relationship in their study based on German stock markets. Babu and Kumar (2015) documented that negative sentiment influences the NSE index return more as compared to positive sentiments. The findings of Zheng (2020) mentioned a noteworthy influence of investor sentiment on stock market return volatility. The findings of P.H. and Rishad (2020) mentioned that irrational sentiment results in high market volatility. These results are relevant for retail investors and portfolio managers pursuing to frame an investment portfolio for profit maximization. Empirical results of the work of Abdelmalek (2021), mentioned that the volatility index is a better instrument for measuring investors' sentiments. Liston, Huerata, and Haq (2021) mentioned that transformations in investor sentiment are positively associated with Shariah-compliant market portfolios.

\section{Hypotheses of the Study}

Based on the literature review and objective of the study, following hypotheses are formulated:

$\mathrm{H}_{\mathrm{a} 1}$ : There is a significant association between investor sentiment and selected sectoral indices return volatility.

$\mathrm{H}_{\mathrm{a} 2}$ : There is a significant impact of investor sentiment on selected sectoral indices' return volatility.

\section{Research Methodology}

\subsection{Variables Selection}

It is a secondary data-based study, collected from the NSE's official website. In the research study, the monthly return of nine sectoral indices for five years from 2015-2019 is taken. The data analysis is conducted by using MS Excel and EViews software. Nine sectoral indices which are selected for data collection are NIFTY Oil and Gases, NIFTY Metal, NIFTY Media, NIFTY FMCG, NIFTY Financial Service, NIFTY Consumer Durables, NIFTY Auto, NIFTY Bank, and NIFTY IT. In this study, investor sentiment is the independent variable whereas stock return volatility is the dependent variable.

\subsection{Model Development}

The methodology of Bollerslev's (1986) is referred. For analysis of serial correlation, Engle's (1982)'s $\mathrm{ARCH}$ and ARCH-LM tests have been used. Compounded log-returns of monthly closing prices of 
Impact of Investors' Sentiments on Selected Sectoral Indices Return Volatility: Special Reference to NSE

sectoral indices are used. It was followed by deduction of the risk-free interest rate to get excess return. Macroeconomic variables monthly data are taken from the databases at the website of the Reserve Bank of India. Due to the unavailability of a definitive investor sentiment indicator in existing literature, many studies have taken up different proxies for it. Existing literature ascertains various methods to characterize the unobservable sentiment index like a survey (Brown and Cliff, 2005) or market-related implicit sentiment proxy variables (Baker and Wurgler, 2006; Li, 2014). Due to inherent shortcomings of the survey method, various latest studies have applied market proxies as investor sentiment indicators. Based on literature review, this study used Mutual Funds Net Flow (MFNF), Put-Call Ratios (PCR), Advance Declining Ratios (ADRs), NIPO, turnover rates (TURN), PE ratios (PER), and trading volumes (TV) as proxies to frame investor sentiment index. MFNF has been used as a proxy as mutual fund flow recommends the relevance of a chosen asset class and a financial alternative for the market participants (Brown and Cliff, 2004 and Chi et al. 2012). PCR is the ratio of market trading sizes of put-call options (Brown and Cliff, 2004). ADR is the ratio of increasing or decreasing stock prices to identify the current stock market movement (Brown and Cliff, 2004; and Dash and Mahakud 2013). NIPO has been taken as a proxy as demand for IPO is normally affected by the market situation (Brown and Cliff, 2004 and Li, 2014). TURN and TV denote the level of stock market liquidity (Zhu, 2012; Li 2014 and Chuang et al. 2010). Price to Earnings Ratio (PER) specifies a stock's market price and the listed companies' financial position (Sehgal et al., 2009 and Zhu, 2012).

Methodologies of Baker and Wurgler (2006) and Verma and Soydemir (2009) is referred to frame sentiment index. In this process, six macroeconomic variables are selected for regressing market proxies. Selected macroeconomic variables are the inflation rate (INF), foreign institutional investors' net investment (FINI), exchange rate (EXRT), Industrial production index's growth rate (IIP), term spread (TS), and short-term interest rate (INT). All market-related proxies are regressed on the selected macroeconomic variables. This process will result in removal of variations due to business cycle from all sentiment proxies even before framing final sentiment index. For this, the following equation has been assessed:

Here,

$$
Y_{t}=\alpha_{0}+\beta_{k}+\text { MacFund }_{k t}+\varepsilon_{t}
$$

- $Y t=$ Market-related implicit sentiment proxies,

- $\alpha 0=$ Constant,

- $\beta \mathrm{k}=$ Parameter to be estimated,

- $\quad$ MacFund $=$ Macroeconomic fundamentals,

- $\mathrm{K}=$ Number of macroeconomic fundamentals,

- $\varepsilon \mathrm{t}=$ Error term.

Following the work of Verma and Soydemir, (2009), equation (i) will give the rational elements, and the residuals will give the irrational element of sentiment. Residual values obtained from equation (i) have been used for the orthogonal implicit sentiment proxies and for framing market sentiment index by using the PCA. The PCA is used to compress the larger number of variables into a smaller number of factors that explain the maximum variance in the original values. After getting the factor loadings, based on the following formula sentiment index has been framed: 


$$
\text { SentIndext }=\sum_{j=1}^{k} a\left(\frac{Y t}{\sigma Y t}\right)
$$

Here,

- $\quad$ aj $=$ Factor loadings for $j$-th item,

- $\mathrm{K}=$ Number of sentiment proxies used,

- $\mathrm{Yt}=$ Sentiment proxies,

- $\sigma \mathrm{Yt}=$ Standard deviation of sentiment proxies.

Following the recommendation of Baker and Wurgler (2006) the final sentiment index (FSI) in this work is framed by calculating raw sentiment index (RSI) based on seven sentiment proxies with their lags. This gave 14-factor loading values. The next step was to calculate the correlation coefficient amongst the RSI (framed in the last step) and the proxies with lags. Finally, the variables with higher correlation with the RSI are chosen either with or without lags and then the FSI is framed. The PCA having $36 \%$ variance gave the following equation of RSI:

$$
\begin{aligned}
\mathrm{RSI}_{t}=0.002 \mathrm{ADR}_{t}+0.623 \mathrm{PCR}_{t-1}+0.636 \mathrm{NIPO}_{t}+0.538 \mathrm{PER}_{t}+0.211 T U R \mathrm{UN}_{t}-0.231 \mathrm{TV} \mathrm{t}_{t} \\
-1-0.34 \mathrm{MFNI}_{t-1}
\end{aligned}
$$

The correlation coefficient among both sentiment indexes (RSI and FSI) is 0.937 , indicating that possibility of missing out on relevant data by removing proxies is very low.

\section{Data Analysis and Interpretation}

\subsection{Trend of Associations}

Figure 1 shows an association among both sentiment indexes (RSI and FSI). A close association between these two sentiment indices is evident. Figure 2 shows the association between RSI and all the sectoral indices. The selected indices display a comparable trend. Figure 3 depicts the association among FSl and RSI, sectoral indices, and market excess return. It can be observed that all the lines are closely placed except excess return. It is also evident from the figure that sectoral indices and excess market return are in direct relation with each other, as when one rises the other also rises, and vice-versa.

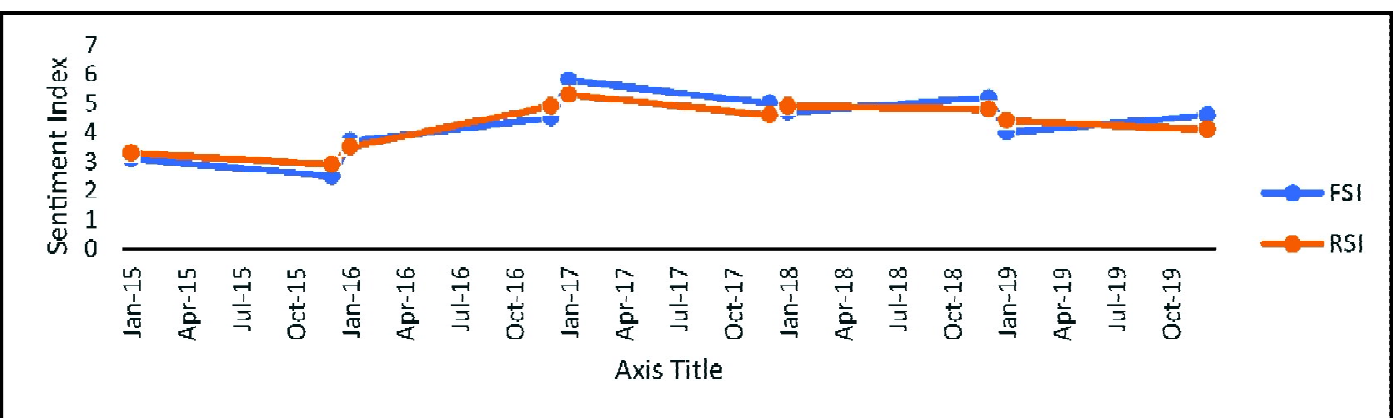

Figure 1: Trend of Association among the RSI and the FSI

Source: Author's Calculation 
Impact of Investors' Sentiments on Selected Sectoral Indices Return Volatility: Special Reference to NSE

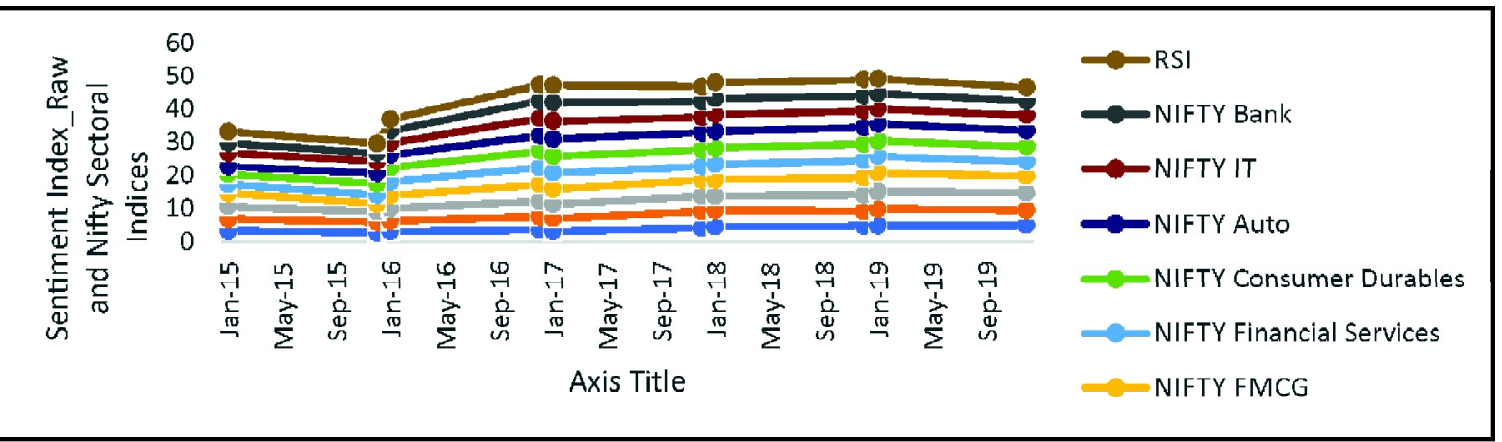

Figure 2: Trend of Association among RSI and the all the Sectoral Indices

Source: Author's Calculation

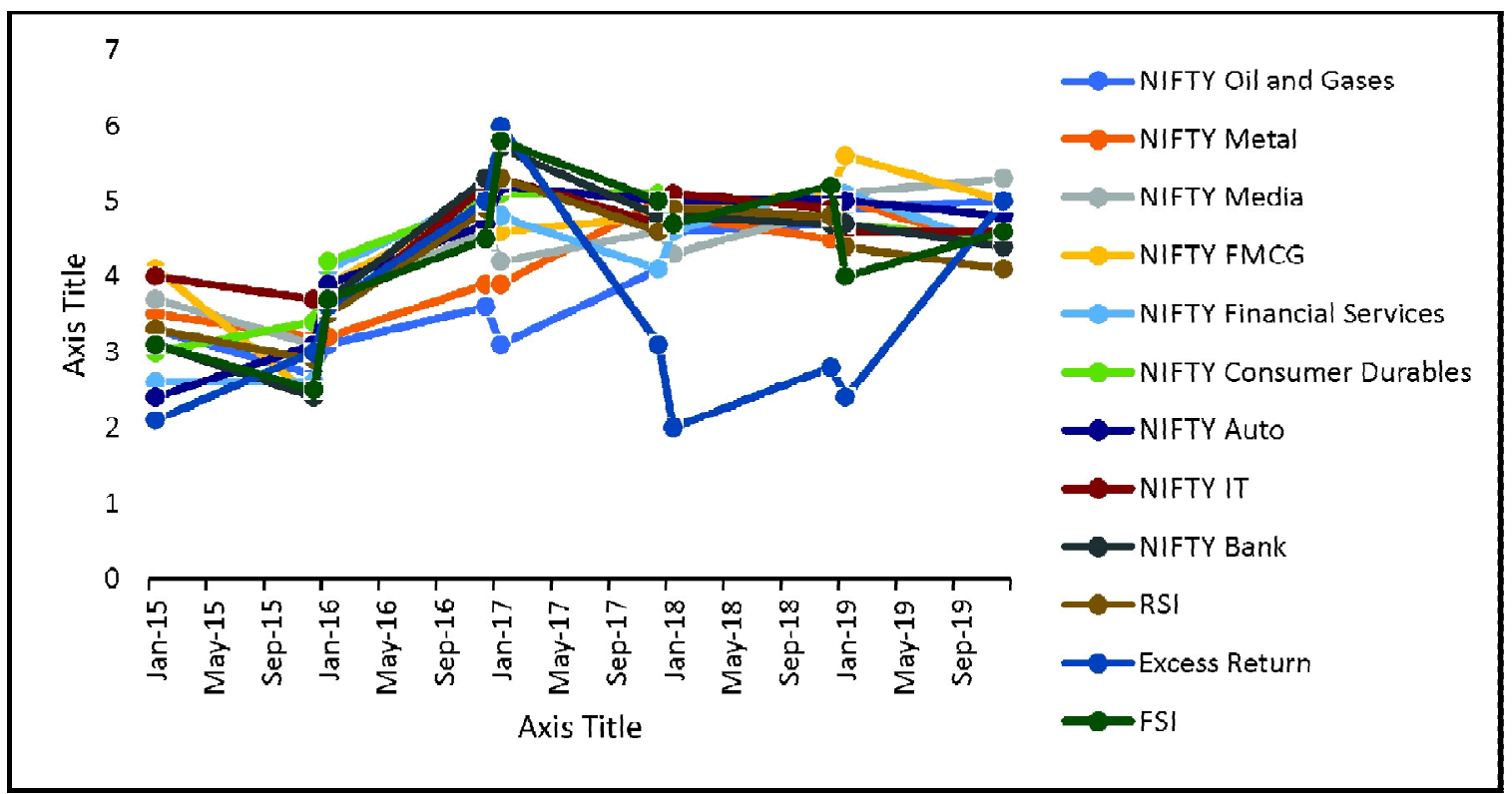

Figure 3: Trends of Association among FSI and RSI, Sectoral Indices and Market Excess Return

Source: Author's Calculation

\subsection{Models and Results}

Table 1 mentions that the mean values of all the sentiment indicators are positive excluding MFNI. This negative mean value of MFNI signifies that the mutual fund investors are normally inclined towards selling more relative to their purchases. The positive value of PCR depicts the bearish sentiment of the market. The mean values of ADR, PER and the market liquidity measure show the signs of good performance of the market. Market performance is also validated through the mean values of 
Pooja Chaturvedi Sharma

NIFTY sectoral indices. Jarque-Bera test is applied for checking data normality. The test statistic shows that logged values are giving a normal distribution.

Table 1: Descriptive Statistics for Market-related Sentiment Proxies, Macroeconomic Factors, and Nine Sectoral Indices

\begin{tabular}{|c|c|c|c|c|c|c|c|c|}
\hline Variables & Mean & $\operatorname{Max}$ & Min & Std. Dev. & Skewness & Kurtosis & Jarque-Bera & Prob. \\
\hline \multicolumn{9}{|c|}{ Market-related sentiment proxies } \\
\hline PCR & 0.848 & 1.581 & 0.220 & 0.242 & -0.472 & 2.998 & 5.279 & 0.07 \\
\hline ADR & 0.903 & 1.904 & 0.481 & 0.119 & 0.873 & 4.128 & 23.730 & 0.00 \\
\hline NIPO & 4 & 29 & 1 & 3.981 & 1.355 & 4.871 & 125.161 & 0.00 \\
\hline TV & 851.07 & 2671.00 & 99.021 & 321.871 & -0.098 & 2.152 & 14.615 & 0.00 \\
\hline PER & 18.069 & 31.549 & 10.270 & 2.010 & 0.451 & 2.055 & 3.761 & 0.23 \\
\hline MFNI & -161.85 & 9873.1 & -5781.1 & 3212.6 & 0.474 & 5.981 & 87.326 & 0.00 \\
\hline TURN & 178315 & 678142 & 26781 & 112345 & 0.496 & 2.901 & 7.461 & 0.07 \\
\hline \multicolumn{9}{|c|}{ Macroeconomic Factors } \\
\hline WPI Growth & 0.648 & 5.342 & -2.301 & 0.723 & -0.499 & 5.760 & 59.011 & 0.00 \\
\hline IIP Growth & 0.851 & 20.241 & -16.562 & 5.431 & -0.203 & 3.697 & 4.671 & 0.08 \\
\hline TBill91 & 7.935 & 14.304 & 4.182 & 2.691 & 0.203 & 2.681 & 2.511 & 0.49 \\
\hline EXRT & 54.239 & 74.265 & 41.741 & 3.762 & 1.302 & 5.085 & 79.124 & 0.00 \\
\hline TS & 0.281 & 4.451 & -2.981 & 0.561 & 0.681 & 8.429 & 261.619 & 0.00 \\
\hline FIINI & 5361.46 & 51233.0 & -54901 & 11230.7 & -0.009 & 6.360 & 82.324 & 0.00 \\
\hline \multicolumn{9}{|c|}{ Stock Market Sectoral Indices } \\
\hline $\begin{array}{l}\text { NIFTY Oil } \\
\text { and Gases }\end{array}$ & 4058.31 & 5393.62 & 2586.68 & 888.145 & -0.2255 & 1.46823 & 130.996 & 0.01 \\
\hline NIFTY Metal & 2796.364 & 4195.7 & 1495.6 & 648.061 & 0.02142 & 2.17402 & 35.1442 & 0.02 \\
\hline NIFTY Media & 2610.248 & 3642.7 & 1707.2 & 455.53 & 0.10138 & 2.08605 & 45.026 & 0.03 \\
\hline NIFTY FMCG & 24862.0 & 32911. & 18094 & 4225.3 & 0.10204 & 1.4995 & 117.80 & 0.08 \\
\hline $\begin{array}{l}\text { NIFTY Financial } \\
\text { Services }\end{array}$ & 9537.46 & 14679. & 5689.9 & 2230.5 & 0.33320 & 1.98617 & 75.622 & 0.08 \\
\hline $\begin{array}{l}\text { NIFTY Consumer } \\
\text { Durables }\end{array}$ & 11011.9 & 17108. & 6661.9 & 3179.1 & 0.19446 & 1.53668 & 117.78 & 0.09 \\
\hline NIFTY Auto & 9271.1 & 12009 & 6763.7 & 1324.1 & 0.28850 & 1.85886 & 84.004 & 0.06 \\
\hline NIFTY IT & 12924.1 & 16705 & 830 & 2197.2 & $(0.31)$ & 4.01894 & 56.555 & 0.04 \\
\hline NIFTY Bank & 24322 & 32412 & 13555 & 4319.4 & -0.2114 & 2.00368 & 46.517 & 0.07 \\
\hline
\end{tabular}

Source: Author's Calculation 
Impact of Investors' Sentiments on Selected Sectoral Indices Return Volatility: Special Reference to NSE

Table 2: Correlation Matrix

\begin{tabular}{lccccccc}
\hline & $P C R$ & $A D R$ & NIPO & TV & PER & MFNI & TURN \\
\hline PCR & 1 & & & & & & \\
ADR & 0.014 & 1 & & & & & \\
NIPO & 0.501 & -0.061 & 1 & & & & \\
TV & -0.058 & 0.213 & -0.052 & 1 & & & \\
PER & 0.423 & 0.211 & 0.381 & -0.061 & 1 & & \\
MFNI & -0.159 & -0.052 & -0.082 & 0.071 & -0.270 & 1 & 1 \\
TURN & 0.082 & 0.151 & 0.048 & 0.779 & 0.028 & 0.041 & 1 \\
\hline
\end{tabular}

Source: Author's Calculation

Note: Table shows the correlation values of selected market related orthogonal sentiment proxies.

Table 2 shows that despite lesser magnitudes, largely all the proxies are positively associated. Table 3 shows positive but extremely small sized mean values of both sentiment indexes and are resultantly insufficient to rationalize a bullish market sentiment. Excess return during the period is -1.965 . Though, a positive association amongst the RSI and FSI and the excess returns can be observed. This is evident of the fact that Indian investors become highly cautious at the downward trend in the market and resultantly the market sentiment declines. Thus, it can be interpreted that with a positive change in sentiment the excess return increases, and with a negative change in sentiment the excess return decreases.

Table 3: Descriptive Statistics of RSI, FSI and Market Excess Return

\begin{tabular}{lccc}
\hline Parameter & FSI & RSI & Excess Return \\
\hline Mean & 0.014 & 0.003 & -1.965 \\
Median & 0.048 & 0.080 & -1.561 \\
Max & 4.682 & 5.013 & 2.091 \\
Min & -1.981 & -2.706 & -0.523 \\
Std. Dev & 1.591 & 1.983 & 1.138 \\
Skewness & 0.302 & 0.284 & -0.984 \\
Kurtosis & 3.005 & 2.989 & 5.942 \\
Jarque Bera & 2.833 & 3.065 & 47.922 \\
Probability & 0.371 & 0.304 & 0.000 \\
Observations & 60 & 60 & 60 \\
FSI & 1 & Correlation Matrix & 1 \\
RSI & 0.937 & 1 & $-5.852^{* *}$ \\
Excess Return & 0.341 & ADF Test Statistics & $(0.000)$ \\
ADF $t$-Stat & $-5.328^{* *}$ & $-3.703 *$ & $(0.064)$ \\
\end{tabular}

Source: Author's Calculation

Notes: $\quad$ FSI $=$ Final Sentiment Index, RSI $=$ Raw Sentiment Index, Values in parenthesis in ADF are the probability values. ${ }^{*}$ and ${ }^{* *}$ shows values are statistically significant at $10 \%$ and $1 \%$ level respectively. 
Before applying advanced data analysis techniques, data stationary properties of all sectoral indices are checked through ADF unit root tests in table 4. The stationary properties of the Sentiment Indices and Excess Return are also confirmed by ADF test (refer Table 3). The estimates indicate that both Sentiment Indices and Excess Return and all sectoral indices are stationary at level.

Table 4: ADF Test Statistics for Sectoral Indices

\begin{tabular}{lcc}
\hline Variables & ADF t-Stat & P values \\
\hline NIFTY Bank & -3.563 & 0.00 \\
NIFTY Auto & -4.725 & 0.02 \\
NIFTY Consumer Durables & -4.673 & 0.03 \\
NIFTY Financial Services & -3.199 & 0.00 \\
NIFTY FMCG & -6.452 & 0.00 \\
NIFTY IT & -3.543 & 0.03 \\
NIFTY Media & -4.378 & 0.00 \\
NIFTY Metal & -5.432 & 0.00 \\
NIFTY Oil and Gases & -2.453 & 0.00 \\
\hline
\end{tabular}

Source: Author's Calculation

For capturing volatility symmetry in financial returns GARCH model is mostly applied. In this regard, the most prevalent generalized ARCH specification is GARCH $(1,1)$. Estimating ARCH effect is a must for the estimation of nonlinear GARCH models.

Here,

$$
Y_{t}=\alpha+\beta_{0} x_{t}+\varepsilon_{t}
$$

- $Y t=$ Index stock returns and sentiment index,

- $\beta 0=$ Coefficient of the model.

To obscure the limitations of GARCH Model, the exponential GARCH model (EGARCH) was recommended by Nelson (1991). EGARCH is capable to summarise asymmetric effects among asset returns. The non-linear conditional GARCH models are contemplated to be superior than the standard volatility estimation process. Also, to examine the volatility features, ARCH effect has been examined through LM statistics. Table 5 displays related test statistics and indicates the existence of ARCH effect in the sectoral indices and also in the irrational sentiment index.

In this study, both GARCH and EGARCH models have been used to check the continuance of volatility in nine sectoral indices and the constructed FSI. The estimations of both models are shown in table 6 and table 7. GARCH estimations in Table 6 indicates that all coefficients have nonzero values and are highly significant. This proposes that the volatility is endured in the sectoral indices and FSI. Additionally, the values of $\alpha+\beta$ are nearing 1 denoting a high degree of volatility continuance. Henceforth, the GARCH Model apprehended the volatility continuance and volatility clustering proficiently. EGARCH model values in table 7 exhibits the existence of asymmetric volatility in each 
Impact of Investors' Sentiments on Selected Sectoral Indices Return Volatility: Special Reference to NSE

Table 5: ARCH -LM Test Statistics

\begin{tabular}{lcc}
\hline Variables & LM Statistics & $P$ values \\
\hline NIFTY Bank & $4.72^{*}$ & 0.00 \\
NIFTY Auto & 5.31 & 0.02 \\
NIFTY Consumer Durables & 4.05 & 0.03 \\
NIFTY Financial Services & $6.47^{*}$ & 0.00 \\
NIFTY FMCG & $5.31^{*}$ & 0.00 \\
NIFTY IT & 5.01 & 0.03 \\
NIFTY Media & $6.15^{*}$ & 0.00 \\
NIFTY Metal & $5.72^{*}$ & 0.00 \\
NIFTY Oil and Gases & $5.31^{*}$ & 0.00 \\
FSI & $6.71^{*}$ & 0.00 \\
\hline
\end{tabular}

Source: Author's calculation

Note: $\quad$ LM Statistics = Lagrange Multiplier, *signifies the presence of statistically significant ARCH effect for all sectoral indices at $1 \%$ level of significance.

variable because $\delta<0$ for all sectoral indices and FSI. These results agree with the studies of Chinzara (2011) and Verma and Verma (2007).

Table 6: Estimates of Volatility Models: GARCH Model Estimates

\begin{tabular}{lcccccccccc}
\hline & $\begin{array}{c}\text { Nifty } \\
\text { Bank }\end{array}$ & $\begin{array}{c}\text { Nifty } \\
\text { Auto }\end{array}$ & $\begin{array}{c}\text { Nifty } \\
\text { Consumer } \\
\text { durables }\end{array}$ & $\begin{array}{c}\text { Financial } \\
\text { services }\end{array}$ & $\begin{array}{c}\text { Nifty } \\
\text { FMCG }\end{array}$ & $\begin{array}{c}\text { Nifty } \\
I T\end{array}$ & $\begin{array}{c}\text { Nifty } \\
\text { Media }\end{array}$ & $\begin{array}{c}\text { Nifty } \\
\text { Metal }\end{array}$ & $\begin{array}{c}\text { Nifty Oil } \\
\text { and Gases }\end{array}$ & FSI \\
\hline$\omega$ & 0.005 & 0.003 & 0.021 & 0.026 & 0.004 & 0.033 & 0.0039 & 0.004 & 0.019 & 8.671 \\
$\alpha$ & $0.102^{*}$ & $0.192^{*}$ & $0.081^{*}$ & $0.276^{*}$ & $0.296^{*}$ & $0.071^{*}$ & $0.261^{*}$ & $0.172^{*}$ & $0.141^{*}$ & $0.597^{* *}$ \\
$\beta$ & $0.734^{*}$ & $0.712^{*}$ & $0.701^{*}$ & $0.694^{*}$ & $0.671^{*}$ & $0.844^{*}$ & $0.693^{*}$ & $0.766^{*}$ & $0.812^{*}$ & $0.392^{* *}$ \\
$\alpha+\beta$ & 0.836 & 0.904 & 0.782 & 0.97 & 0.967 & 0.915 & 0.954 & 0.938 & 0.953 & 0.989 \\
ARCH- & 3.98 & 4.89 & 3.87 & 5.81 & 5.02 & 4.63 & 5.87 & 5.20 & 4.89 & 0.897 \\
LM & $(0.51)$ & $(0.45)$ & $(0.58)$ & $(0.59)$ & $(0.41)$ & $(0.56)$ & $(0.54)$ & $(0.49)$ & $(0.56)$ & $(0.92)$ \\
ARCH- & 4.86 & 3.77 & 4.50 & 6.22 & 4.52 & 3.94 & 6.89 & 7.47 & 5.04 & 0.067 \\
LM ${ }^{2}$ & $(0.68)$ & $(0.74)$ & $(0.66)$ & $(0.71)$ & $(0.54)$ & $(0.62)$ & $(0.78)$ & $(0.86)$ & $(0.56)$ & $(0.95)$ \\
LL & 289.76 & 168.98 & 253.12 & 325.75 & 256.70 & 189.47 & 375.86 & 410.65 & 302.75 & 473.56 \\
SIC & -2.65 & -1.96 & -2.21 & -3.46 & -2.32 & -2.06 & -3.57 & -3.89 & -2.96 & 6.65 \\
\hline
\end{tabular}

Source: Author's calculation

GARCH and E-GARCH Models have competently captured the asymmetric volatility and effect of leverage. Here, ARCH-LM test of residuals and squared residuals proposes that both selected models summarised the continuance in volatility aptly and is observable by insignificant ARCH-LM 
Pooja Chaturvedi Sharma

Table 7: Estimates of Volatility Models: EGARCH Model Estimates

\begin{tabular}{lcccccccccc}
\hline & $\begin{array}{c}\text { Niffy } \\
\text { Bank }\end{array}$ & $\begin{array}{c}\text { Niffy } \\
\text { Auto }\end{array}$ & $\begin{array}{c}\text { Niffy } \\
\text { Consumer } \\
\text { durables }\end{array}$ & $\begin{array}{c}\text { Finftycial } \\
\text { services }\end{array}$ & $\begin{array}{c}\text { Nifty } \\
\text { FMCG }\end{array}$ & $\begin{array}{c}\text { Nifty } \\
\text { IT }\end{array}$ & $\begin{array}{c}\text { Niffy } \\
\text { Media }\end{array}$ & $\begin{array}{c}\text { Nifty } \\
\text { Metal }\end{array}$ & $\begin{array}{c}\text { Nifty } \\
\text { Oil and } \\
\text { Gases }\end{array}$ & FSI \\
\hline$\omega$ & -2.345 & -2.647 & -1.990 & -2.762 & -2.668 & -2.181 & -1.891 & -1.988 & -2.441 & 2.034 \\
$\alpha$ & $0.3^{* *}$ & $0.561^{* *}$ & $0.249^{* *}$ & $0.612^{* *}$ & $0.681^{* *}$ & $0.213^{* *}$ & $0.675^{* *}$ & $0.516^{* *}$ & $0.419^{* *}$ & $0.682^{* *}$ \\
$\beta$ & $0.452^{* *}$ & $0.412^{* *}$ & $0.399^{* *}$ & $0.361^{* *}$ & $0.300^{* *}$ & $0.671^{* *}$ & $0.305^{* *}$ & $0.417^{* *}$ & $0.548^{* *}$ & $0.303^{* *}$ \\
$\alpha+\beta$ & 0.752 & 0.973 & 0.648 & 0.973 & 0.981 & 0.884 & 0.980 & 0.933 & 0.967 & 0.985 \\
$\delta$ & -0.152 & -0.341 & -0.214 & -0.162 & -0.144 & -0.233 & -0.141 & -0.098 & -0.112 & -0.564 \\
ARCH- & 2.67 & 3.21 & 3.01 & 4.09 & 3.89 & 3.26 & 4.01 & 3.92 & 3.51 & 4.97 \\
LM & $(0.59)$ & $(0.57)$ & $(0.64)$ & $(0.65)$ & $(0.54)$ & $(0.67)$ & $(0.61)$ & $(0.56)$ & $(0.68)$ & $(0.46)$ \\
ARCH- & 3.98 & 3.05 & 3.90 & 5.71 & 5.64 & 4.97 & 5.84 & 5.13 & 4.89 & 2.03 \\
LM $^{2}$ & $(0.76)$ & $(0.54)$ & $(0.73)$ & $(0.83)$ & $(0.55)$ & $(0.69)$ & $(0.58)$ & $(0.59)$ & $(0.64)$ & $(0.89)$ \\
LL $_{\text {SIC }}^{296.5}$ & -2.59 & -1.91 & -2.13 & -3.29 & -2.01 & -1.97 & -3.38 & -3.66 & -2.89 & 6.49 \\
\hline
\end{tabular}

Source: Author's calculation

Note: $\omega$ symbolizes the constant values, $\alpha$ symbolizes the ARCH term, $\beta$ the GARCH term, and $\alpha+\beta$ symbolizes the stationary condition of model and volatility persistence. Values in parenthesis in ARCH-LM tests are the respective $\mathrm{p}$-values, ${ }^{*}$ and ${ }^{* *}$ signifies values are statistically significant at $1 \%$ and $5 \%$, respectively.

and $\mathrm{ARCH}-\mathrm{LM}^{2}$ values (Table 6 and table 7). Loglikelihood value and SIC criteria are used to choose the best model from GARCH and EGARCH. According to the selection benchmark better model should have a lower SIC value. According to SIC value EGARCH model is better than GARCH model (Table 6 and Table 7). So, for further analysis EGARCH model has been used. Bivariate VAR has been used to get the conditional volatility for sectoral indices and FSI from the selected EGARCH model. It is also found that the volatility of sectoral indices and FSI is positively skewed and kurtotic.

Table 8: Descriptive Statistics of EGARCH Model

\begin{tabular}{lcccccccccc}
\hline & $\begin{array}{c}\text { Nifty } \\
\text { Bank }\end{array}$ & $\begin{array}{c}\text { Nifty } \\
\text { Auto }\end{array}$ & $\begin{array}{c}\text { Nifty } \\
\text { Consumer } \\
\text { durables }\end{array}$ & $\begin{array}{c}\text { Financial } \\
\text { services }\end{array}$ & $\begin{array}{c}\text { Nifty } \\
\text { FMCG }\end{array}$ & $\begin{array}{c}\text { Nifty } \\
\text { IT }\end{array}$ & $\begin{array}{c}\text { Nifty } \\
\text { Media }\end{array}$ & $\begin{array}{c}\text { Nifty } \\
\text { Metal }\end{array}$ & $\begin{array}{c}\text { Nifty } \\
\text { Oil and } \\
\text { Gases }\end{array}$ & FSI \\
\hline M & 0.004 & 0.004 & 0.0052 & 0.004 & 0.05 & 0.005 & 0.005 & 0.004 & 0.004 & 0.006 \\
SD & 0.001 & 1.001 & 00.001 & 0.001 & 0.01 & 0.001 & 0.002 & 0.001 & 0.001 & 0.032 \\
Skewness & 1.234 & 1.145 & 1.8981 & 1.763 & 1.80 & 1.845 & 2.561 & 1.799 & 1.678 & 0.764 \\
Kurtosis & 4.611 & 4.987 & 6.0412 & 5.213 & 5.40 & 5.612 & 6.562 & 5.311 & 5.871 & 3.435 \\
Jarque Bera & 113.7181 & 29.5454 & 48.43 & 145.83 & 87.60 & 146.008 & 80.5478 & 46.9859 & 37.9875 & 207.7531 \\
Observations & 60 & 60 & 60 & 60 & 60 & 60 & 60 & 60 & 60 & 60 \\
\hline
\end{tabular}

Source: Author's Calculation

Note: Table shows summarised descriptive statistics for EGARCH Model of all sectoral indices and FSI. 
Impact of Investors' Sentiments on Selected Sectoral Indices Return Volatility: Special Reference to NSE

Bivariate VAR has been applied to analyse the relationship between sectoral indices volatility and investor sentiment volatility. Table 9 and table 10 shows that VAR values are significant for all sectoral indices. This specifies that investor sentiment volatility plays an imperative role in affecting market volatility. This finding is validated in the work of Verma and Verma (2007). It entails that besides macroeconomic factors related to non-diversifiable risk and company fundamentals related diversifiable risk, sentiment risk also plays an important role in defining market volatility. In this work, VAR statistics are statistically insignificant for sectoral indices volatility and indicates that sectoral indices volatility does not impact investors' psychology. Hiremath and Kumari (2014) show significant variation in Indian sectoral indices with proficiency. Results of this study are also in consensus with the same.

Table 9: Bivariate VAR F Statistics

\begin{tabular}{lc}
\hline \multicolumn{2}{c}{ Predictive Power of Stock Market Volatility } \\
\hline NIFTY Bank & \\
NIFTY Auto & $1.46(0.34)$ \\
NIFTY Consumer Durables & $1.90(0.67)$ \\
NIFTY Financial Services & $0.54(0.53)$ \\
NIFTY FMCG & $1.56(0.31)$ \\
NIFTY IT & $0.76(0.55)$ \\
NIFTY Media & $0.80(0.21)$ \\
NIFTY Metal & $1.66(0.83)$ \\
NIFTY Oil and Gases & $0.75(0.79)$ \\
\hline
\end{tabular}

Source: Author's Calculation

Table 10: Bivariate VAR F Statistics

\begin{tabular}{ll}
\hline \multicolumn{2}{c}{ Predictive power of sentiment volatility } \\
\hline NIFTY Bank & $3.91^{*}(0.00)$ \\
NIFTY Auto & $5.63^{*}(0.04)$ \\
NIFTY Consumer Durables & $6.09^{*}(0.00)$ \\
NIFTY Financial Services & $5.52^{*}(0.02)$ \\
NIFTY FMCG & $6.81^{*}(0.00)$ \\
NIFTY IT & $4.10^{*}(0.00)$ \\
NIFTY Media & $4.86^{*}(0.00)$ \\
NIFTY Metal & $5.83^{*}(0.00)$ \\
NIFTY Oil and Gases & $4.65^{*}(0.01)$ \\
\hline
\end{tabular}

Source: Author's Calculation

Note: Parentheses values are the respective p values. F statistic's critical values are $1.57(5 \%)$ and $1.42(10 \%)$. * Indicates values are statistically significant @ 5\% level. 
Pooja Chaturvedi Sharma

\section{Findings}

The study deals with affiliation among investor's sentiments and selected sectoral indices volatility in the Indian Stock Market. The ADF unit root test was applied to the data and was found that the data is stationary. Results showed that ARCH effect is present in all sectoral indices and FSI. The most suitable model for volatility modeling of the sectoral indices was the EGARCH model. The results of EGARCH model depicted the existence of volatility asymmetry in all variables. The bivariate VAR values indicate a unidirectional connection between investor sentiment volatility and sectoral indices volatility. On detailed hypotheses testing, both $\mathrm{H}_{\mathrm{a} 1}$ and $\mathrm{H}_{\mathrm{a} 2}$ have been accepted. As this study revealed significant affiliation among the investor sentiment and sectoral indices return volatility although it is different in different sectors according to product type. Regarding investor's sentiments, the findings validate that investor sentiment is a pertinent component in elucidating returns and conditional variance. Higher the current market volatility, higher would be the impact of investor sentiment due to the influence of various behavioural biases.

\section{Conclusion}

The researcher constructed a FSI in the context of selected Indian sectoral indices. In this study, data analysis was done in a very detailed manner starting with GARCH and EGARCH models to get conditional volatility. This study revealed continuance and asymmetry of volatility in selected Indian sectoral indices and investor sentiment. The bivariate VAR results depicted a unidirectional connection between investor sentiment and sectoral indices volatility. The results of this work will have theoretical implications along with implications for investors and the government. This study will develop a literature base of behavioural finance by focusing on investor sentiment in sectoral indices. This study will also work as a bridge between qualitative and quantitative dimensions of finance and will give readers a new understanding of finance. The investors can use the results of this study to take guidance for further investments and also learn about the association between investor's sentiments and sectoral indices return volatility. At the government policy framing level, these results may offer some insights related to the preparation and execution of suitable policies to support the Indian financial market to stabilize. Limitations of this study are smaller data as only five years data has been considered and limited number of sectoral indices have been selected for analysis. Although various sectoral indices were used in this study, in future researches other indices can be added to the comparative work. Also, investor sentiment can be used to forecast the trends due to extreme financial market volatility like price bubble bursts. Researching sentiments and earnings response can be explored more as earning periods are extremely volatile and backed by investors' emotional involvement.

\section{References}

Abdelmalek, W. (2021). Investor sentiment, realized volatility and stock returns. Review of Behavioral Finance, ahead-of-print, https://doi.org/10.1108/RBF-12-2020-0301.

Audrino, F., Sigrist, F., and Ballinari, D. (2020). The impact of sentiment and attention measures on stock market volatility. International Journal of Forecasting, 36 (2), 334-357. 
Baker, M. \& J. Wurgler (2006). Investor Sentiment and the Cross-section of Stock Returns. Journal of Finance, 61(4), 1645-80.

Baker, M. \& J. Wurgler (2007). Investor Sentiment in the Stock Market. Journal of Economic Perspectives, 21(2), 129151.

Black, F. (1976). Studies of Stock Price Volatility Changes, Proceedings of the Business and Economics Section of the American Statistical Association, 177-181.

Bollerslev, T. (1986). Generalized autoregressive conditional heteroskedasticity. Journal of Econometrics, .31, 307327.

Brown, G. W. \& M. T. Cliff (2004). Investor Sentiment and the Near-term Stock Market. Journal of Empirical Finance, 11(1), 1-27.

Brown, G. W. \& M. T. Cliff (2005). Investor Sentiment and Asset Valuation. The Journal of Business, 78(2), 405440.

Chen, M.P., Chen, P.-F., \& Lee, C.C. (2013). Asymmetric effects of investor sentiment on industry stock returns: Panel data evidence. Emerging Markets Review, 14(0), 35-54.

Chi, L., Zhuang, X. \& Song, D. (2012). Investor sentiment in the Chinese stock market: An empirical analysis, Applied Economic Letters, 19, 345-348.

Chinzara, Z. (2011). Macroeconomic uncertainty and conditional stock market volatility in South Africa. South African Journal of Economics, 79, 27-49.

Chuang, W. J., Ouyang, L.Y., and Lo, W.C. (2010). The impact of investor sentiment on excess returns: a Taiwan market cases. International Journal of Information and Management Sciences, 21, 13-28.

Chung, S.L., Hung, C.H. \&Yeh, C.Y. (2012). When does investor sentiment predict stock returns? Journal of Empirical Finance, 19(2), 217-240.

Dash, R.S., \& Mahakud, J., (2013). Investor Sentiment and Stock Return: Do Industries Matter? Margin: The Journal of Applied Economic Research, 7(3), 315-349.

Engle, R. F. (1982). Autoregressive conditional heteroskedasticity with estimates of the variance of United Kingdom inflation. Econometrica, 50, 987-1007.

Finter, P., Niessen, A., \& Ruenzi, S. (2010). The impact of investor sentiment on the German stock market. Journal of Business Economics, 82 (2).

Henderson, B.J., Jegadeesh, N., \& Weisbach, M. (2006). World markets for raising new capital. Journal of Financial Economics, 82 (1), 63-101

Hiremath, G. S., \& Kumari, J. (2014). Stock returns predictability and the adaptive market hypothesis in emerging markets: Evidence from India. Springer Plus, 3, 1-14.

Kim, K., \& Nofsinger, J. (2008). Behavioral finance in Asia. Pacific-Basin Finance Journal, (16), 1-7.

Kling, G., \& Gao, L. (2008). Chinese institutional investors' sentiment. Journal of International Financial Markets, Institutions and Money, (18), 374-387.

Lee, C. M. C., Shleifer, A., \& Thaler, R. H. (1991). Investor sentiment and the closed-end fund puzzle. Journal of Finance, 46, 75-109.

Li, B.H. (2014). Does investor sentiment predict stock returns? The evidence from Chinese stock market. Journal of System Science Complex, 27, 130-143.

Orissa Journal of Commerce, 42(1) (C) 2021 
Pooja Chaturvedi Sharma

Ling, D. C., Naranjo, A., \& Scheick, B. (2013). Investor Sentiment, Limits to Arbitrage and Private Market Returns. Real Estate Economics,42(3), 531-77.

Liston, P.D., Huerta, D. \& Haq, S. (2016). Does investor sentiment impact the returns and volatility of Islamic equities? Journal of Economics and Finance, 40, 421-437.

Nelson, D. B. (1991). Conditional heteroskedasticity in asset returns: A new approach. Econometrica, 59, $347-$ 370.

P.H, H., \& Rishad, A. (2020). An empirical examination of investor sentiment and stock market volatility: evidence from India. Financial Innovation, 6 (34).

Raju, M.T. \& Ghosh, A. (2004). Stock market volatility-An International Comparison, Securities and Exchange Board of India.

Sehgal, S., Sood, G.S. \& Rajput, N. (2009). Investor sentiment in India: a survey. Vision: The Journal of Business Perspective, 13, 13-23.

Shefrin, H. (2015). Investors' Judgments, Asset Pricing Factors and Sentiment. European Financial Management, 21(2), 205-227.

Uhl, M. W. (2014). Reuter's sentiment and stock returns, Journal of Behavioral Finance, 15(4), 287-298.

Verma, R. \& Soydemir, G. (2009). The impact of individual and institutional investor sentiment on the market price of risk. The Quarterly Review of Economics and Finance, 49, 1129-1145.

Verma, R. \& Verma, P. (2007). Noise trading and stock market volatility. Journal of Multinational Financial Management, $17,231-243$.

Zhang, C. (2008). Defining, modeling, and measuring investor sentiment. Working paper, Department of Economics. Berkeley: University of California.

Zheng, J. (2020). How does Investor Sentiment have Impacts on Stock Returns and Volatility in the Growth Enterprise Market in China? Thesis submitted to the University of Ottawa in partial Fulfillment of the requirements for the Master of Science in Management (Finance), Telfer School of Management, University of Ottawa, Canada.

Zhu, X. (2012). Investor sentiment and volatility of stock index an empirical analysis from the perspective of behavioral finance. Advances in Applied Economics and Finance, 3 (4), 627-629. 